\title{
Determination of Nutritional Aspects and Antioxidant Properties of Gonads of Red Sea Urchin- Salmacis bicolor ${ }^{\dagger}$
}

\author{
M. Gobala Krishnan ${ }^{1}$, S.R. Radhika Rajasree ${ }^{2, *}$, L. Aranganathan ${ }^{1}$, M.G. Karthih ${ }^{1}$ \\ 1 Centre for Ocean Research (DST - FIST Sponsored Centre), Sathyabama Institute of Science and Technology, Jeppiaar \\ Nagar, Rajiv Gandhi Salai, Chennai 600 119, Tamil Nadu, India \\ 2 Department of Fish Processing Technology, Kerala University of Fisheries and Ocean Studies (KUFOS), Cochin 682506, \\ Kerala, India \\ * Correspondence: radhikarajasree@kufos.ac.in; \\ $\dagger$ Presented at International e-Conference on Bioengineering for Health and Environment (ICBHE 2020)
}

Received: 5.07.2020; Revised: 10.07.2020; Accepted: 12.07.2020; Published: 15.07.2020

\begin{abstract}
Sea urchin gonads are of high economic significance owing to its multi-nutritional properties. The present study investigated the proximate composition, spectroscopic quantification of mineral, and fatty acid contents using ICP-OES and GC-MS and antioxidant properties of gonads of Salmacis bicolor. Proximate analysis revealed presence of moisture (71.93 $\pm 0.23 \%)$; ash $(1.89 \pm 0.23 \%)$; protein $(9.25 \pm 0.33 \%)$; lipids $(12.31 \pm 0.225 \%)$ and carbohydrate $(4.62 \pm 0.67 \%)$ on dry weight basis. ICPOES detected high concentrations of $\mathrm{Na}(265.10 \pm 0.23 \mu \mathrm{g} / \mathrm{L}) ; \mathrm{Ca}(172.90 \pm 0.11 \mu \mathrm{g} / \mathrm{L})$; good levels of $\mathrm{Mg}(88.42 \pm 0.34 \mu \mathrm{g} / \mathrm{L})$ and $\mathrm{K}(40.325 \pm 0.12 \mu \mathrm{g} / \mathrm{L})$. GC-MS revealed high concentration of fatty acids such as heptadecenoic acid methyl ester (C17:0 - 25.07 $\pm 0.1 \mathrm{mg} / \mathrm{ml})$, cis -10-heptadecenoic acid methyl ester $(\mathrm{C} 17: 1-23.98 \pm 0.18 \mathrm{mg} / \mathrm{ml})$, pentadecanoic acid methyl ester $(\mathrm{C} 15: 0-19.1 \pm 0.19 \mathrm{mg} / \mathrm{ml})$ and palmitic acid methyl ester $(\mathrm{C} 16: 0-12.01 \pm 0.21 \mathrm{mg} / \mathrm{ml})$. The gonads were identified to be good source of amino acids: lysine $(432.12 \pm 0.16 \mathrm{mg} / \mathrm{g})$, valine $(256.21 \pm 0.18 \mathrm{mg} / \mathrm{g})$; isoleucine $(235.31 \pm 0.27$ $\mathrm{mg} / \mathrm{g})$, leucine $(312.12 \pm 0.12 \mathrm{mg} / \mathrm{g})$ and histidine $(156.45 \pm 0.23 \mathrm{mg} / \mathrm{g})$. S. bicolor gonads were estimated to contain antioxidants: total phenol content ( $8.354 \mathrm{mg} \mathrm{GAE} / \mathrm{g})$ and flavonoid content $(10 \mathrm{mg}$ QE/g). DPPH assay identified good radical scavenging effects with $\mathrm{IC}_{50}$ calculated to be $61.53 \mathrm{mg} / \mathrm{ml}$. Hence it is concluded that gonads of S. bicolor possess could be considered as a good source of nutrients such as amino and fatty acids and antioxidants for human consumption.
\end{abstract}

Keywords: Salmacis bicolor; Gonads; ICP-OES; Fatty acids; Antioxidants.

(C) 2020 by the authors. This article is an open-access article distributed under the terms and conditions of the Creative Commons Attribution (CC BY) license (https://creativecommons.org/licenses/by/4.0/).

\section{Funding}

This research received no external funding.

\section{Acknowledgments}

This research has no acknowledgment.

\section{Conflicts of Interest}

The authors declare no conflict of interest. 